\title{
Correction to: Association of food insecurity with frailty among older adults in India
}

\author{
Mamta Chaudhary ${ }^{1}$
}

Published online: 17 January 2018

(C) Springer-Verlag GmbH Germany, part of Springer Nature 2017, corrected publication January/2018

\section{Correction to: J Public Health}

https://doi.org/10.1007/s10389-017-0866-4

The real name of the author is Mamta Chaudhary.

The original article has been corrected.

The online version of the original article can be found at https://doi.org/ 10.1007/s10389-017-0866-4.

$\triangle$ Mamta Chaudhary

chauhdarymamta092@gmail.com

1 Tata Institute of Social Sciences, Mumbai, India 